Atmos. Chem. Phys., 12, 4909-4921, 2012

www.atmos-chem-phys.net/12/4909/2012/

doi:10.5194/acp-12-4909-2012

(C) Author(s) 2012. CC Attribution 3.0 License.

\title{
Iodine monoxide in the north subtropical free troposphere
}

\author{
O. Puentedura ${ }^{1}$, M. Gil ${ }^{1}$, A. Saiz-Lopez ${ }^{2}$, T. Hay ${ }^{2}$, M. Navarro-Comas ${ }^{1}$, A. Gómez-Pelaez ${ }^{3}$, E. Cuevas ${ }^{3}$, J. Iglesias ${ }^{1}$, \\ and L. Gomez ${ }^{1}$ \\ ${ }^{1}$ Instituto Nacional de Técnica Aeroespacial (INTA), Área de Investigación e Instrumentación Atmosférica, Ctra Ajalvir km4, \\ 28850, Torrejón de Ardoz, Madrid, Spain \\ ${ }^{2}$ Laboratory for Atmospheric and Climate Science, CSIC, Toledo, Spain \\ ${ }^{3}$ Centro de Investigación Atmosférica de Izaña (Agencia Estatal de Meteorología - AEMET), Sta, Cruz de Tenerife, Spain
}

Correspondence to: O. Puentedura (puentero@inta.es)

Received: 12 August 2011 - Published in Atmos. Chem. Phys. Discuss.: 12 October 2011

Revised: 2 April 2012 - Accepted: 16 May 2012 - Published: 6 June 2012

\begin{abstract}
Iodine monoxide (IO) differential slant column densities (DSCD) have been retrieved from a new multi-axis differential optical absorption spectroscopy (MAX-DOAS) instrument deployed at the Izaña subtropical observatory as part of the Network for the Detection of Atmospheric Composition Change (NDACC) programme. The station is located at $2370 \mathrm{~m}$ a.s.l., well above the trade wind inversion that limits the top of the marine boundary layer, and hence is representative of the free troposphere. We report daily observations from May to August 2010 at different viewing angles. During this period, the spectral signature of IO was unequivocally detected on every day of measurement. A mean IO DSCD of $1.52 \times 10^{13}$ molecules $\mathrm{cm}^{-2}$ was observed at the $5^{\circ}$ instrument elevation angle (IEA) on clear days using a single zenith reference for the reported period, with a day-to-day variability of $33 \%$ at one standard deviation. Based on the simulation of the DSCDs using radiative transfer calculations with five different hypothesized IO profiles, the IO mixing ratio is estimated to range between 0.2 and $0.4 \mathrm{pptv}$ in the free troposphere. Episodes of Saharan dust outbreaks were also observed, with large increases in the DSCDs at higher IEA, suggesting an enhancement of IO inside the dust cloud.
\end{abstract}

\section{Introduction}

UV-visible spectroscopy has, for decades, been used for stratospheric chemistry studies. In recent years, improvements in the Differential Optical Absorption Spectroscopy (DOAS) technique and advances in profile retrievals from Multi Axis-DOAS (MAX-DOAS) observation modes (Platt and Stutz, 2008) have made possible the detection of trace gases of tropospheric interest at very low concentrations. Among them, the detection of iodine monoxide (IO) in the marine boundary layer (MBL) has been reported by numerous studies (Alicke et al., 1999; Allan et al., 2000; SaizLopez et al., 2007; Read et al., 2008). IO is involved in catalytic cycles of ozone loss in the MBL (e.g. Chameides and Davis, 1980), enhances the ozone depletion capacity of other halogen radicals such as $\mathrm{BrO}$ and intervenes in the release of $\mathrm{Cl}$ and $\mathrm{Br}$ from sea-salt (Vogt et al., 1999; McFiggans et al., 2000). Iodine chemistry has also been postulated to have an effect in modulating the ratios of $\mathrm{OH} / \mathrm{HO}_{2}$ and $\mathrm{NO} / \mathrm{NO}_{2}$ (e.g. Davis et al., 1996; Bloss et al., 2005) and in the formation of new particles at coastal sites that can potentially act as cloud condensation nuclei in the MBL (e.g. O'Dowd et al., 2002).

Measurements of tropospheric IO have been mostly located in mid-latitude marine coastal areas such as Mace Head, Ireland (Alicke et al., 1999; Saiz-Lopez and Plane, 2004; Huang et al., 2010) and Roscoff, France (Peters et al., 2005; Wada et al., 2007; Whalley et al., 2007; Mahajan et al., 2009) where its detection is conditioned to the biogenic activity when some species of algae are exposed to the atmosphere, emitting mainly $I_{2}$ at low tide (Saiz-Lopez and Plane, 2004). Therefore, the concentrations of IO measured in these field campaigns are highly variable (between 1 and $9.8 \mathrm{pptv}$ ).

IO has also been measured under open ocean conditions. Observed concentrations are significantly lower than at coastal locations and with little annual variation (Mahajan et al., 2010). Observations performed during dedicated campaigns at Tenerife (Allan et al., 2000) and Cape Verde (Read et al., 2008) reported concentrations between 0.2 and 4 pptv. 
IO has also been detected from space over high southern latitudes using the SCIAMACHY instrument (Saiz-Lopez et al., 2007; Schönhardt et al., 2008). However, at mid and low latitudes, the IO signal-to-noise ratio is too low for SCIAMACHY retrievals, except over biologically active regions (Schönhardt et al., 2008).

Recently, measurements using the MAX-DOAS technique from a ship cruise between the Canary Islands, Cape Verde and the Mauritania coast during June 2010 (Grossmann et al., 2011) have shown very small amounts of IO close to the detection limit near the Tenerife Coast.

Field campaigns to detect IO have all been concentrated in the MBL, whereas attempts to detect the molecule in the free troposphere (FT) are scarce. Butz et al. (2008) reported an upper limit of $0.1 \mathrm{pptv}$ at $13.5 \mathrm{~km}$ as measured by balloonborne instrumentation using the solar occultation technique. Unfortunately, solar occultation does not allow observations of lower layers and the vertical distribution of IO within the troposphere still remains uncertain.

In this paper we report on the first observation of IO in the FT using MAX-DOAS at the Izaña observatory over three months of measurements from 25 May 2010 to 17 August 2010. Descriptions of the meteorology at the measurement site, the instrument, the DOAS retrieval and the radiative transfer model for calculation of box-air-mass factors (boxAMFs) are given in Sects. 2, 3 and 4 respectively. Results and discussion are then presented in Sect. 5 and conclusions are given in Sect. 6.

\section{Station description and meteorology}

The Izaña Atmospheric Observatory is part of the Global Atmospheric Watch (GAW) programme and is managed by the CIAI (Centro de Investigación Atmosférica de Izaña) belonging to the Agencia Estatal de Meteorología (AEMET, Spain). It is located at $28^{\circ} 18^{\prime} \mathrm{N}, 16^{\circ} 29^{\prime} \mathrm{W}$ in Tenerife (the Canary Islands), $300 \mathrm{~km}$ from the African west coast at an altitude of $2370 \mathrm{~m}$ a.s.l. The Canary Islands are below the descending branch of the Hadley Cell, which favours a large scale high stability subsidence flow regime, resulting in a large number of clear-sky days per year and a quasi-permanent strong temperature inversion (trade wind inversion) established between 800 and $1500 \mathrm{~m}$ a.s.l. (Font, 1956; Milford et al., 2008) depending on time of day and season. A persistent sea of clouds at the inversion base is an almost permanent feature at Tenerife. This fact is due to the condensation resulting from up-forcing of the trade winds when encountering the north face of the island and convection by surface solar heating transporting moisture and tracers vertically upwards. At any time of the year, the base of the inversion defining an upper limit to the MBL lies well below the level of the observatory, precluding pollution from the Sta. Cruz and Puerto de la Cruz coastal towns from reaching the station at night, except for occasions associated with the passing of low pressure

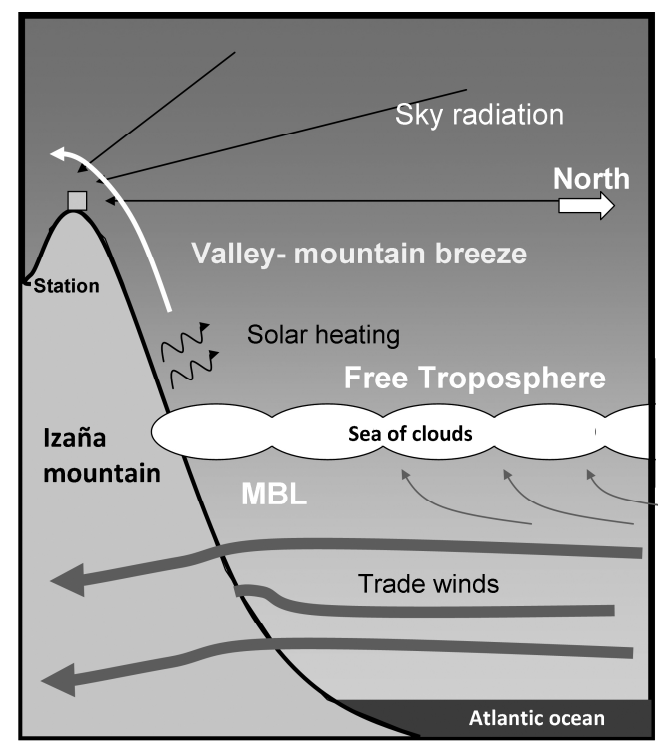

Fig. 1. Schematic view of the Izaña station from the East face. The sea of clouds drifts between $800 \mathrm{~m}$ in summer months to $1500 \mathrm{~m}$ in winter months.

systems. Trade winds, initially forced to ascend due to the orography, stop ascending and surround the island when they reach the inversion level. During daytime, a valley-mountain breeze, driven by solar heating, acts as a local mechanism to transport air from the well mixed MBL top up to the station level. Molecules such as $\mathrm{CO}_{2}, \mathrm{O}_{3}$ and $\mathrm{H}_{2} \mathrm{O}$ can be used as tracers since their concentration in the MBL and FT are very different. This breeze is superimposed on the synoptic wind, which is dominant at the level of the station. The stronger the synoptic wind the lesser the influence of the upwelling breeze on in-situ measurements. Its potential effect on the interpretation of measurements presented in this work will be considered later. Figure 1 shows a scheme of the station profile.

\section{Experimental}

\subsection{Instrument description}

A RASAS-II MAX-DOAS spectrometer collected scattered radiation from the sky in the $415-530 \mathrm{~nm}$ spectral range. It was based on a Shamrok SR-163i spectrograph and a $1024 \times 255$ pixels DU420A-BU Andor Idus CCD camera. A circulating cryostat, containing ethylene-glycol, helped to keep the detector stabilized at the operation temperature of $-30^{\circ} \mathrm{C}$ in order to minimize dark current. Light entered the spectrograph through a fused silica round-to-line fibre bundle. The fibre end was 100 microns in width. The diffraction grating was holographic with 1200 grooves $\mathrm{mm}^{-1}$ blazed at $300 \mathrm{~nm}$. 
Table 1. Instrumental and analysis settings for IO retrieval.

\begin{tabular}{|c|c|c|}
\hline \multicolumn{3}{|c|}{ Instrumental } \\
\hline FWHM & & $0.52-0.58 \mathrm{~nm}$ \\
\hline Linear dispersion & & $0.11 \mathrm{~nm} /$ pixel \\
\hline F.O.V. & & $6.5^{\circ}$ \\
\hline Instrument Elevation Angles (IEA) & & $90^{\circ}, 70^{\circ}, 30^{\circ}, 10^{\circ}, 5^{\circ}, 3^{\circ}, 2^{\circ}, 1^{\circ}, 0^{\circ},-1^{\circ}$ \\
\hline Azimuth & & Fixed to North \\
\hline Time for collecting a single spectrum & & From $0.2 \mathrm{~s}$ at noon to $10 \mathrm{~s}$ at $90^{\circ} \mathrm{SZA}$ \\
\hline Time for a single measurement & & Spectra co-added for $90 \mathrm{~s}$ \\
\hline Time of a complete cycle & & $4 \mathrm{~min}$ \\
\hline \multicolumn{3}{|c|}{ Fit parameters } \\
\hline Spectral interval & & $417-440 \mathrm{~nm}$ \\
\hline Orthogonalization Polynomial & & 3rd degree \\
\hline Offset & & Inverse of the reference \\
\hline Reference spectrum & & A single one for all period. At zenith and $\mathrm{SZA}=50^{\circ}$ \\
\hline \multicolumn{3}{|c|}{ Absorption Cross-sections } \\
\hline Molecule & Temperature & Reference \\
\hline $\mathrm{O}_{3}\left(\mathrm{I}_{0}=10^{19}\right.$ molec $\left.\mathrm{cm}^{-2}\right)$ & $223 \mathrm{~K}$ and $243 \mathrm{~K}$ & Bogumil et al. (2000) \\
\hline $\mathrm{NO}_{2}\left(\mathrm{I}_{0}=5 \times 10^{16}\right.$ molec $\left.\mathrm{cm}^{-2}\right)$ & $220 \mathrm{~K}$ and $298 \mathrm{~K}$ & Vandaele et al. (2002) \\
\hline $\mathrm{O}_{4}$ & $298 \mathrm{~K}$ & Greenblatt et al. (1990) \\
\hline IO & $298 \mathrm{~K}$ & Gomez Martin et al. (2005) \\
\hline $\mathrm{H}_{2} \mathrm{O}$ & $298 \mathrm{~K}$ & Rothman et al. (2009) \\
\hline Rot. Raman Scatt. (Ring effect) & & WINDOAS package, Fayt and Van Roozendael (2001) \\
\hline
\end{tabular}

The linear dispersion was $0.11 \mathrm{~nm}$ pixel $^{-1}$. The FWHM of the spectrograph in the selected spectral window ranged between 0.52 and $0.58 \mathrm{~nm}$. An isolated housing, thermally controlled to $\pm 0.1{ }^{\circ} \mathrm{C}$, minimized shifting and squeezing of the spectra due to thermal compression and expansion. In order to prevent condensation, dry nitrogen was continuously pumped at $41 \mathrm{~min}^{-1}$ into the isolated box containing the detector. All critical parameters, such as detector temperature, humidity and housing temperature, were recorded together with the atmospheric spectra. The outer end of the fibre was connected to a black-painted tube and a field of view (FOV) of $6.5^{\circ}$ was defined by a baffling structure. A Quartz window at the fibre tip precluded the entry of dust or water. The entrance optics was attached to a motorized Pan-tilt unit (PTUD47 RS232) manufactured by Direct Perception, enabling it to point to any part of the sky. In-house software controlled the measurement regime, integration time, rejection of saturated spectra, motor movements and instrument ON/OFF switching. Note that the performance of the instrument had already been tested in the CINDI semi-blind intercomparison campaign for MAX-DOAS $\mathrm{NO}_{2}$ measurements during the northern-hemisphere summer of 2009 (Roscoe et al., 2010).

The RASAS-II spectrometer was installed on the terrace of the Izaña Observatory in March 2010 to complement zenith sky measurements carried out since 1993 under the framework of the NDACC. The outdoor optics of the instrument, located in the tower of the observatory, also allowed for mea- surements at negative elevation angles. To minimise the effect of optical path changes due to solar azimuth variation, the instrument was pointed due north (azimuth $=0^{\circ}$ ) (Wittrock et al., 2004). Off-axis measurements were carried out continuously from $85^{\circ} \mathrm{SZA}$ in the morning to $85^{\circ} \mathrm{SZA}$ in the evening. Zenith measurements were skipped around noon close to the summer solstice to avoid direct sunlight in the detector. At each single measurement, spectra were accumulated for approximately $90 \mathrm{~s}$ depending on the time of year. A complete cycle of elevations took about $4 \mathrm{~min}$. Main instrumental and measurement parameters are summarized in Table 1.

\subsection{IO retrieval}

The analysis of spectra was performed using software developed at INTA based on the standard DOAS technique (Platt and Stutz, 2008). A detailed explanation of the analysis routine can be found in Gil et al., 2008. IO was retrieved in the spectral interval from 417 to $440 \mathrm{~nm}$, where three vibrational bands in the $\mathrm{A}^{2} \prod_{3 / 2} \leftarrow \mathrm{X}^{2} \prod_{3 / 2}$ electronic transition can be observed. Using this spectral range, interferences from $\mathrm{O}_{4}$ are mostly avoided. In addition to $\mathrm{IO}, \mathrm{NO}_{2}, \mathrm{O}_{3}, \mathrm{O}_{4}$ and $\mathrm{H}_{2} \mathrm{O}$ absorption cross-sections were included in the retrieval. Glyoxal was excluded in the final analysis since it was found that the retrieved amounts were not genuine but resulted from interferences with IO. When extending the evaluation range to $460 \mathrm{~nm}$ (to cover Glyoxal large band at $455 \mathrm{~nm}$ ) no signature 


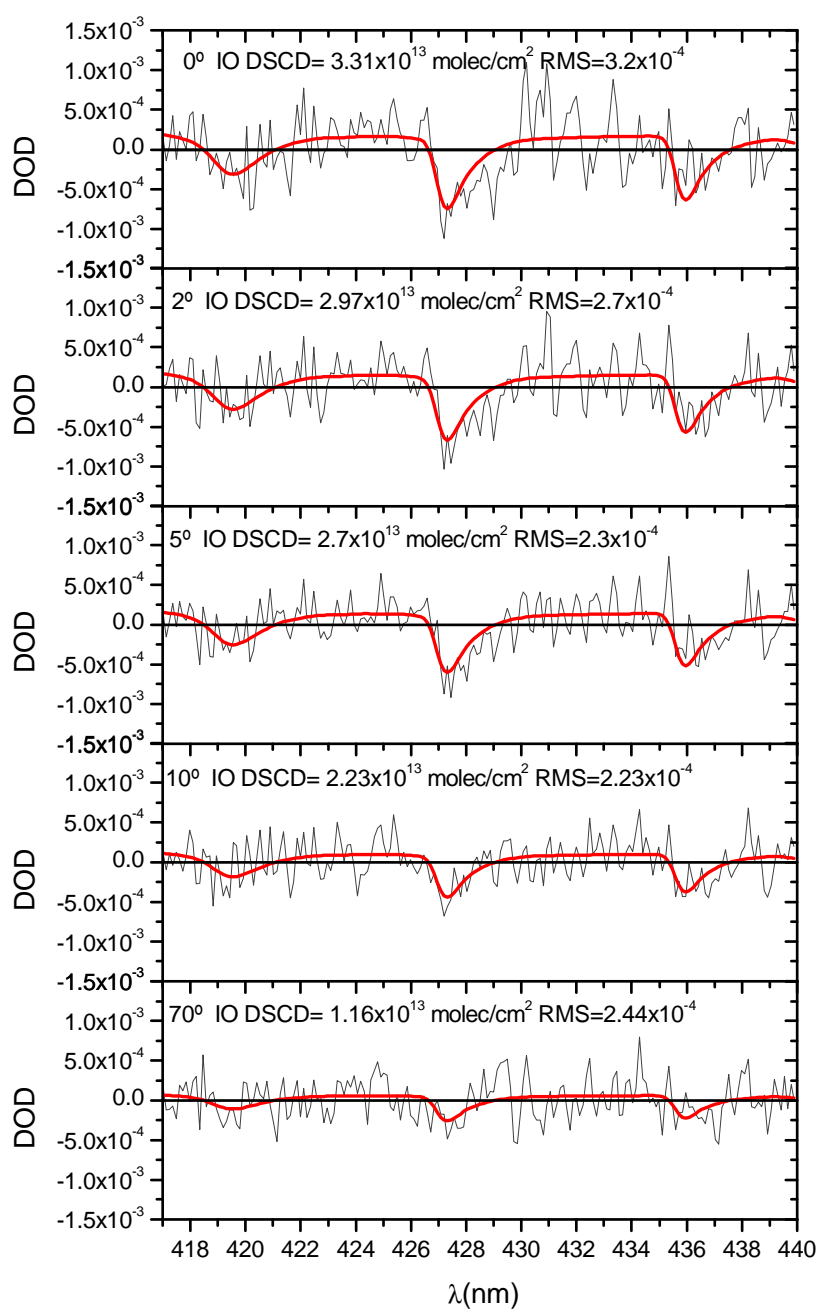

Fig. 2. IO Detected differential optical depth (DOD) for a number of elevation angles on day 180 at approx. $\mathrm{SZA}=70^{\circ} \mathrm{pm}$.

of this species was found in any spectrum. A Raman scattering cross-section was generated by the WinDOAS package (Fayt and Van Roozendael, 2001) based on the algorithm described by Chance and Spurr (1997). Finally, the inverse of the reference spectrum was included as a pseudo-crosssection to account for stray light inside the spectrograph and detector residual dark current.

The settings are summarized in Table 1. For typical RMS errors of the retrieval varying from $2 \times 10^{-4}$ to $5 \times 10^{-4}$, the instrumental detection limit, computed according Platt and Stutz (2008), ranges between $1.7 \times 10^{12}$ and $4.3 \times 10^{12}$ molec cm $^{-2}$. Figure 2 shows examples of IO spectral fits for a number of elevation angles during a single cycle.

\section{Box-AMF calculations}

In order to estimate the sensitivity of the measurements to the presence of IO in different altitude layers, box-AMF calcu- lations taking into account the instrumental FOV have been carried out. A box-AMF is an intensity-weighted air-massfactor (AMF) for a given altitude layer, assuming a homogeneous vertical trace-gas profile within that layer, and it indicates the sensitivity of a SCD to the amount of IO in that layer.

Differential box-AMFs were determined using the NIMO full spherical Monte Carlo radiative transfer model (Hay et al., 2012). The model simulates backward photon trajectories from the instrument to the top of the atmosphere (TOA) using the Monte Carlo technique. Model photons are emitted from the detector entrance optics with an isotropic distribution over the FOV. The photon radiances are then determined for the different measurement geometries by weighting them by the extinction along adjoint trajectories between each scattering location and the TOA in the direction of the Sun as well as the probability of scattering into that direction.

Differential (with respect to the zenith) box-AMFs were calculated for different observation geometries, considering a FOV of $6.5^{\circ}$ and an ocean surface albedo of 0.07 . The aerosol profile used in the simulations had an extinction of $0.1 \mathrm{~km}^{-1}$ at sea level, linearly decreasing to $0.02 \mathrm{~km}^{-1}$ at two km a.s.l., then exponentially decreasing to $0.001 \mathrm{~km}^{-1}$ at six km. a.s.l, with a total optical depth of 0.14 (0.024 above the station) at $550 \mathrm{~nm}$, based on Atlantic Ocean optical depth measurements from Smirnov et al. (1995). Aerosol scattering has been treated using the Henyey-Greenstein parametrisation, with a single scattering albedo of 0.99 and an asymmetry parameter of 0.7 .

Differential box-AMFs were determined both for clear sky and considering a cloud layer located below the observatory between 600 to $1100 \mathrm{~m}$ a.s.l. The altitude range of the inversion has been estimated for typical summer conditions during 2008 to 2011 from the ECMWF 24-h forecast computed at 6 hour intervals. Comparisons with nearby radiosoundings indicate an accuracy in the level of the inversion estimated by the ECMWF forecast better than $70 \mathrm{~m}$ (Alberto Redondas, private communication, 2010). The model cloud layer was considered to be homogeneous with an optical depth of five, a Henyey-Greenstein asymmetry parameter of 0.85 and a single scattering albedo of one. These cloud parameters are based on data taken from the international Satellite Cloud Climatology Project (isccp.giss.nasa.gov) for the Canary Island area during 2010.

\section{Results and discussion}

IO has been observed over the detection limit for low IEAs between $0^{\circ}$ and $10^{\circ}$ on every day. Figure 3 a shows the entire data series for IEA $=0^{\circ}$ and for IEA $=5^{\circ}$. A single reference, recorded on the morning of day 180 (29 June) at $49^{\circ} \mathrm{SZA}$, has been used for the entire period of study. In this work, twilight measurements have not been taken into account since no IO stratospheric contribution to the column is expected. 


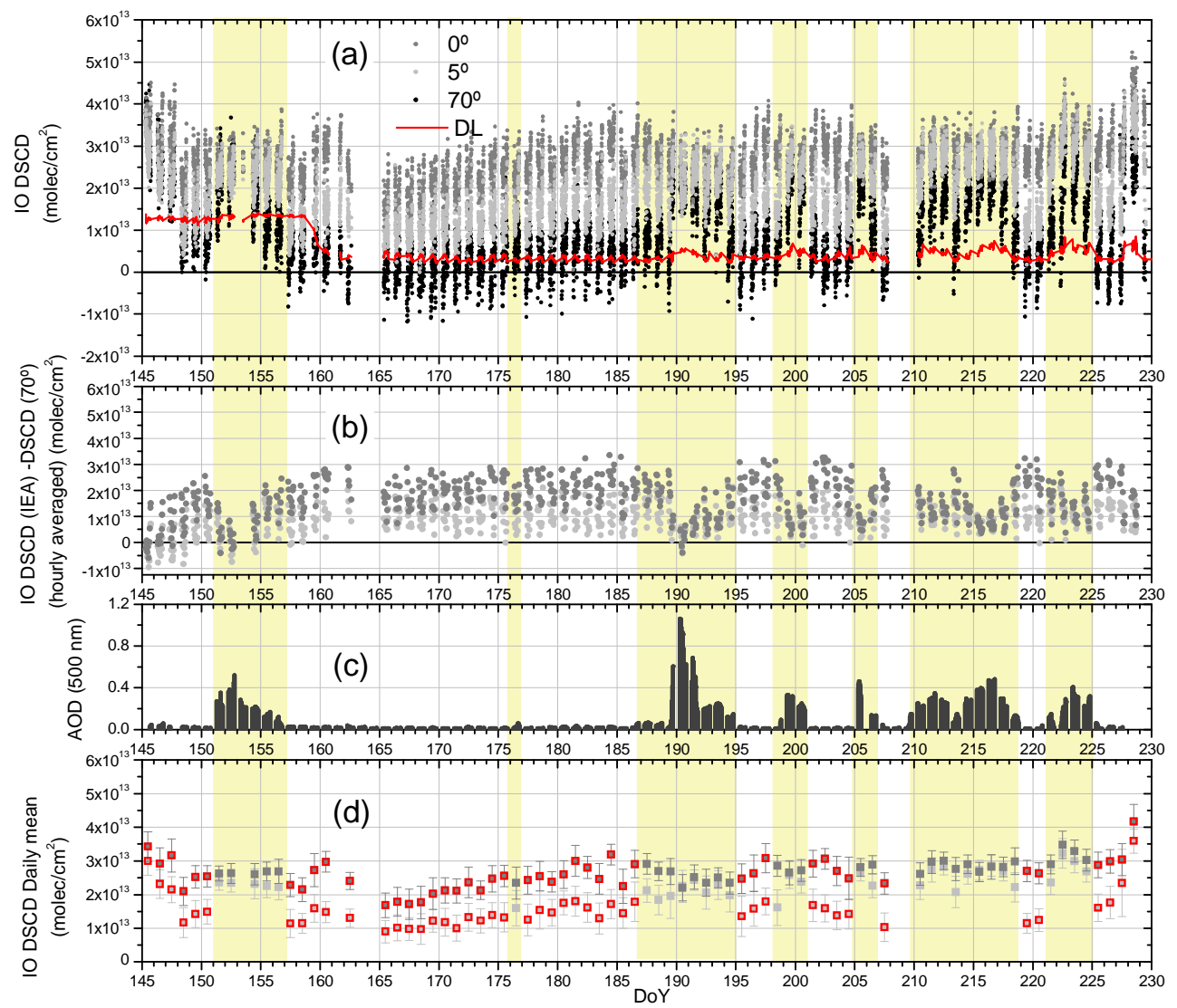

Fig. 3. (a) IO DSCDs for $0^{\circ}, 5^{\circ}$ and $70^{\circ}$ instrument elevation angles elevation evaluated with a single reference taken on the morning of day 180 (29 June) at $49^{\circ}$ SZA. Red line is the detection limit between for $5^{\circ}$ IEA. (b) $0^{\circ}$ and $5^{\circ}$ IEA differences with respect to $70^{\circ}$ IEA for the same measurement cycle (see text). (c) Aerosol optical depths above the station. (d) IO DSCD daily means and standard deviations. Red encircled squares are pristine days. Shaded areas corresponding to Saharan dust events.

The instrument suffered from stabilization problems before day 160 , resulting in high retrieval errors, but performed well during the rest of the period. The measured columns at the $0^{\circ}$ and $5^{\circ}$ IEA are well above the detection limit (Fig. 3a), which is very similar for both elevation angles.

Figure $3 \mathrm{~b}$ shows the difference between the hourly average DSCDs at $0^{\circ}$ and $5^{\circ}$ IEA with respect to the DSCDs at $70^{\circ}$ IEA. The $70^{\circ}$ angle instead of $90^{\circ}$ has been selected to avoid artifacts due to direct sun radiation entering the telescope around noon during the summer months. In the absence of good quality zenith data, the $70^{\circ}$ IEA data provides a useful reference for obtaining the IO density at altitudes near the instrument by removing most of the influence of the day-to-day variability and SZA. Since the time required for a measurement cycle to be completed is small (four minutes), the SZA changes during this time have a negligible impact on the DSCDs. Results show that the differences in column density at different IEAs are reduced or even disappear in selected periods with high aerosol loading above the station. Figure 3c shows the Aerosol Optical Depth (AOD) at $500 \mathrm{~nm}$ cloud-filtered above the station as obtained by the
AERONET-CIMEL photometer located on the terrace of the observatory close to the instrument. As during summertime, subtropical meteorology is dominated by high-pressure systems with a very strong inversion at around $1000 \mathrm{~m}$ a.s.l., MBL aerosols do not penetrate upwards and AOD remains below 0.05 unless Saharan dust intrusions take place. AOD increases are observed only as a result of dust loading, which is the case in a number of events during the period of study.

The measurements extend from late spring to midsummer. During this period when Saharan dust outbreaks, extending vertically up to 6-7 km with an AOD (500 nm) up to one, are not uncommon. Under Saharan dust conditions, multiple scattering enhancement results in a reduction of the optical paths under a highly scattering atmosphere as it will be shown later, making the interpretation of the measurements more challenging. Consequently, only clear days, defined as AOD at $500 \mathrm{~nm}$ less than 0.05 , are considered in the estimation of IO concentrations obtained at the observation site. Daily means IO DSCD for the complete period are shown in Fig. $3 \mathrm{~d}$ for IEA $0^{\circ}$ and $5^{\circ}$. Red encircled dots denote clear days with AOD lower than 0.05 for $0^{\circ}$ (dark grey) and $5^{\circ}$ 

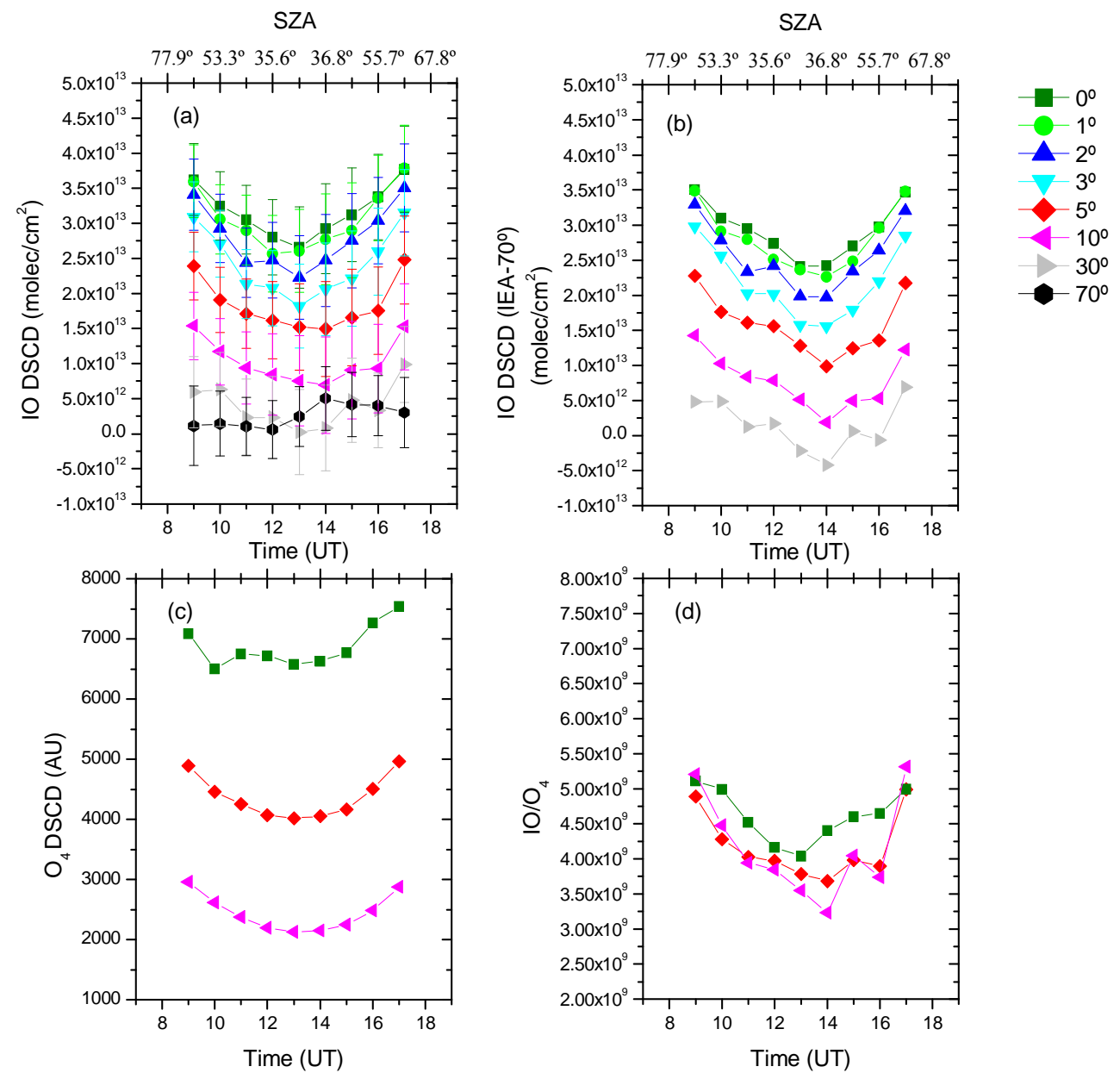

Fig. 4. (a) Diurnal evolution of IO DSCD for elevation angles from $0^{\circ}$ to $70^{\circ}$ during day 278 (5 October). (b) Differences for each elevation in (a) with respect to elevation $70^{\circ}$. (c) $\mathrm{O}_{4}$ diurnal variation on day 278 for a set of elevation angles. (d) $\mathrm{IO}_{\mathrm{O}} \mathrm{O}_{4}$ ratio for the same day. Same color legend has been used to illustrate IEAs for all graphs.

(light grey) IEA respectively. For these days the mean IO DSCD is $2.58 \times 10^{13}$ molec $\mathrm{cm}^{-2}$ with a variation of $18 \%$ at the $1 \sigma$ level for IEA $0^{\circ}$ and $1.52 \times 10^{13}$ molec cm$^{-2}$ with a variation of $33 \%$ at the $1 \sigma$ level for IEA $5^{\circ}$. Note, however, that the period is too short and perturbed by Saharan dust outbreaks to extract any conclusion about the existence of a clear seasonal behaviour.

\subsection{Diurnal evolution}

One clear autumn day yielding low residuals has been selected as an example to illustrate the diurnal evolution of the IO DSCDs. During autumn continuous measurements between twilights are possible, avoiding gaps resulting from instrument switch-off around noon required to prevent detector damage from direct sunlight.

In Fig. 4 the diurnal cycle of IO DSCD measurements is plotted for 5 October (day 278). Panel a shows hourly mean IO DSCD from the standard analysis. As before, only hourly differences with respect to $70^{\circ}$ IEA are shown in Fig. $4 \mathrm{~b}$. At all elevation angles, except at $70^{\circ}$, IO DSCD displays a Ushape with the minimum shifted toward the local afternoon (14:00 UT).

The same IO DSCD diurnal evolution is obtained when $\mathrm{O}_{4}$ DSCD is used as a reference. The ratio of the IO DSCD to the $\mathrm{O}_{4} \mathrm{DSCD}$ is proportional to $\mathrm{IO}-\mathrm{VCD} / \mathrm{O}_{4} \mathrm{VCD}$ under the assumption that the mean scattering altitude of the effective light path and the vertical profile shape are the same for both species. Since $\mathrm{O}_{4}$ is essentially constant with time, variations in the ratio should be due to changes in IO concentrations. In Fig. $4 \mathrm{c}, \mathrm{O}_{4}$ retrieved in the $477 \mathrm{~nm}$ band shows that day 278 was extremely stable above the station. Only data at $0^{\circ}$ elevation angle displays a slight perturbation of the path associated with the vertical movement of the layer just above the MBL, which has little influence on the retrieved IO DSCDs (Fig. 4a). In Fig. 4d, the ratio $\mathrm{IO} / \mathrm{O}_{4}$ of individual simultaneous measurements. Under the previous assumptions changes related to the time differences between zenith and low angle measurements are cancelled out. The results confirm that 
the noon minimum occurs at low elevation angles and is not associated with reductions in the optical path.

This behaviour is typical, as was observed on most of the evaluated days but is opposite to what was previously found at sea level in Tenerife Island (Allan et al., 2000).

The temperature inversion level oscillates throughout the day due to heating/cooling of the surface. The bottom-of-theinversion (BI) lifts around noon approaching the station altitude. If the IO amount observed at noon were related to the oscillation of the BI height, midday maximum values of IO would be expected. Instead, the observed IO U-shape indicates a diurnal behaviour that is not directly related to vertical transport. A possible explanation for the IO minimum around noon is the reaction of $\mathrm{IO}+\mathrm{HO}_{2}$, an important reaction pathway at low IO concentrations, leading to the formation of a temporary iodine reservoir, $\mathrm{HOI}$, at midday when $\mathrm{HO}_{2}$ levels peak in the FT (Martinez et al., 2010). Note also that the IO diurnal behaviour can be different in the MBL and FT as the nature of the reactive iodine precursors is most likely also different.

\subsection{Radiative transfer calculations}

During most of the measurement period, a layer of tradewind clouds extends along the north face of Tenerife Island at the level of the inversion, limiting radiation from the MBL below about $1000 \mathrm{~m}$ a.s.l. Consequently, most of the upward radiation observed by the instrument has previously been scattered from the atmosphere above the clouds or from the top layers of the clouds rather than from below the clouds. Even in the absence of the cloud layer, the intensity of radiation scattered into the instrument from the MBL is negligible compared with the radiation coming from above. However, due to the wide FOV used during the reporting period $\left(6.5^{\circ}\right)$, the amount of radiation received from the MBL at the lowest elevation angles is significantly higher than it would be for a narrow FOV.

Therefore, differential box-AMFs were calculated, as described in Sect. 4, using the NIMO radiative transfer model in order to test the sensitivity of the measurements to various possible IO vertical profiles. Figure 5 shows differential (with respect to the zenith box-AMFs) box-AMFs calculated for IEA $0^{\circ}$ and $5^{\circ}$, and SZA $30^{\circ}$ and $75^{\circ}$, both with and without clouds. For all IEA, the instrument is most sensitive to IO in the layer at the height of the observatory, but at IEA greater than $3^{\circ}$ there is a small contribution to the observations from layers below the instrument and thus a small contribution from the MBL to these observations is expected. This is not the case for IEA $5^{\circ}$ where, according to the boxAMFs, only layers above the instrument contribute to the observations and therefore IEA $5^{\circ}$ DSCDs can be considered as representative of the FT. However, the presence of the cloud renders the contribution from below $1000 \mathrm{~m}$ a.s.l. insignificant.

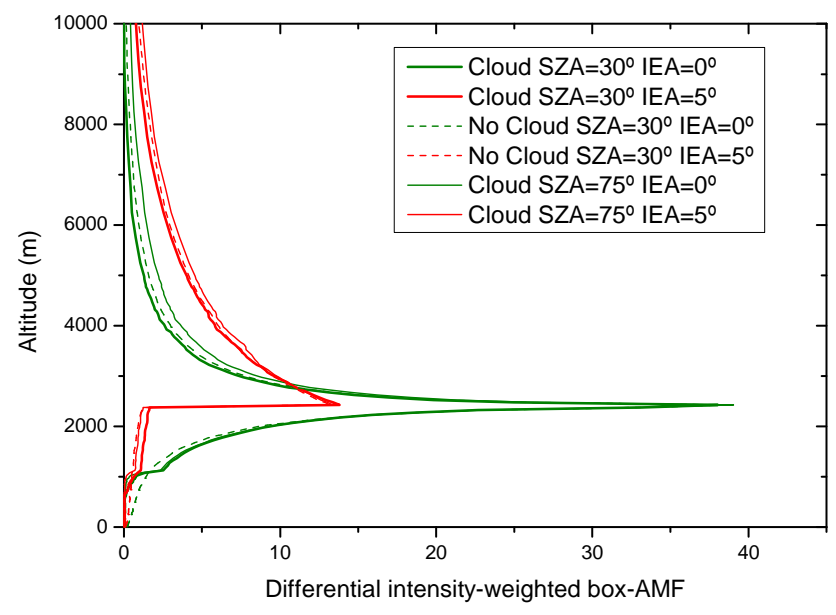

Fig. 5. Differential intensity-weighted box-AMFs for different conditions, elevation angles of observation and solar zenith angles.

Using these differential box-AMFs, model DSCDs were calculated for five different IO profiles, shown in the top panel of Fig. 6. Two of the profiles (profile 2 and 4) included IO only below $1000 \mathrm{~m}$ a.s.l., considering all IO confined to the MBL. The other three profiles contained IO from sea level up to $10000 \mathrm{~m}$ a.s.l. Different IO concentrations, ranging from 0.2 to $4 \mathrm{pptv}$, were used in the calculations, taking into account previous measurements in the MBL at Tenerife (Allan et al., 2000) where a maximum amount of about 4 pptv was found. Profile 5 was calculated using the CAM-Chem chemistry-climate model (Ordoñez et al., 2012; Lamarque et al., 2012). The modelled DSCDs for the $0^{\circ}$ and $5^{\circ}$ IEA are displayed in Fig. 6 (middle and bottom panels) together with the measured DSCDs from day 278. It can be seen that the profiles with IO only in the MBL cannot reproduce the measured DSCDs, whereas the measured DSCDs can be explained by an IO profile with between 0.2 and 0.4 pptv in the FT.

To exclude the possibility of IO coming from the MBL by upwelling, "in situ" water vapour measurements performed at Izaña have been taken into account. $\mathrm{H}_{2} \mathrm{O}$ partial pressure exhibits a diurnal oscillation with maximum values around noon and minimum values at night. The daily Marine Boundary Layer Penetration Index (MBLPI) can be defined as the area contained between the $\mathrm{H}_{2} \mathrm{O}$ partial pressure diurnal variation curve and the straight line joining the minima of the preceding and the subsequent nights. The index takes into account the amplitude and the duration of the upwelling slope breeze and provides information on the injection of air masses from below. MBL concentrations of $\mathrm{H}_{2} \mathrm{O}$ are larger than FT ones and the area is positive since $\mathrm{H}_{2} \mathrm{O}$ increases during the day.

The results show that the breeze is far from being a steady and constant phenomenon, even in warm months (Fig. 7, upper panel), since it is largely dependent on the insolation and 

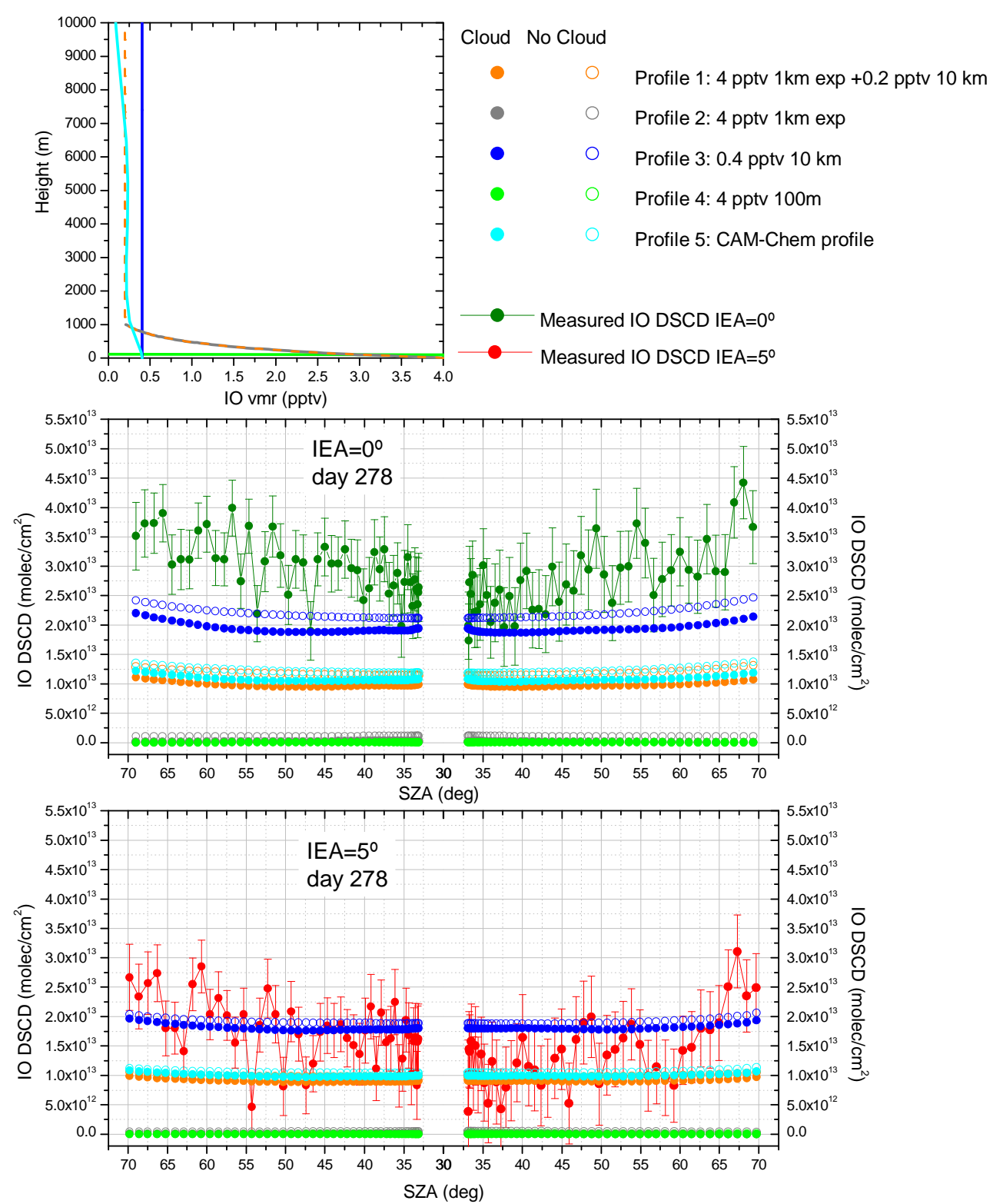

Fig. 6. Top panel, set of different IO profiles used to simulate IO DSCDs at the level of the observatory for IEA $0^{\circ}$ and $5^{\circ}$. Middle panel, simulated IO DSCD using different profiles of IO and comparison with measurements for IEA $=0^{\circ}$. Bottom panel, same for IEA $=5^{\circ}$.

synoptic circulation, but ventilation of MBL air into the FT takes place almost every day. During Saharan dust events, when the southern wind dominates, the breeze disappears. The lack of a clear correlation between the MBLPI and IO is not surprising since the width of the layer of ascending air is of a few hundreds of meters (A. Gómez, private communication, 2010) and the contribution to the signal in MAXDOAS measurements of optical path lengths near $40 \mathrm{~km}$ is very small.

The absence of any other known processes exchanging air on a global scale between the MBL and FT strongly supports the conclusion that the observed IO in the FT represents an almost constant background in the subtropical open ocean FT, at least near the Canary archipelago.

\subsection{Effect of Saharan outbreaks on IO DSCD}

Multiple scattering enhancements occurring during Saharan dust events induce changes in the optical paths. Figure 8 (upper panel) shows how, under these conditions the sky radiance at IEA $70^{\circ}$ increases strongly up to a factor of three at noon as compared to clean days. At the same time, the $0^{\circ}$ elevation radiance decreases on dusty days compared to clean days. The result is a quite uniform radiation distribution on 

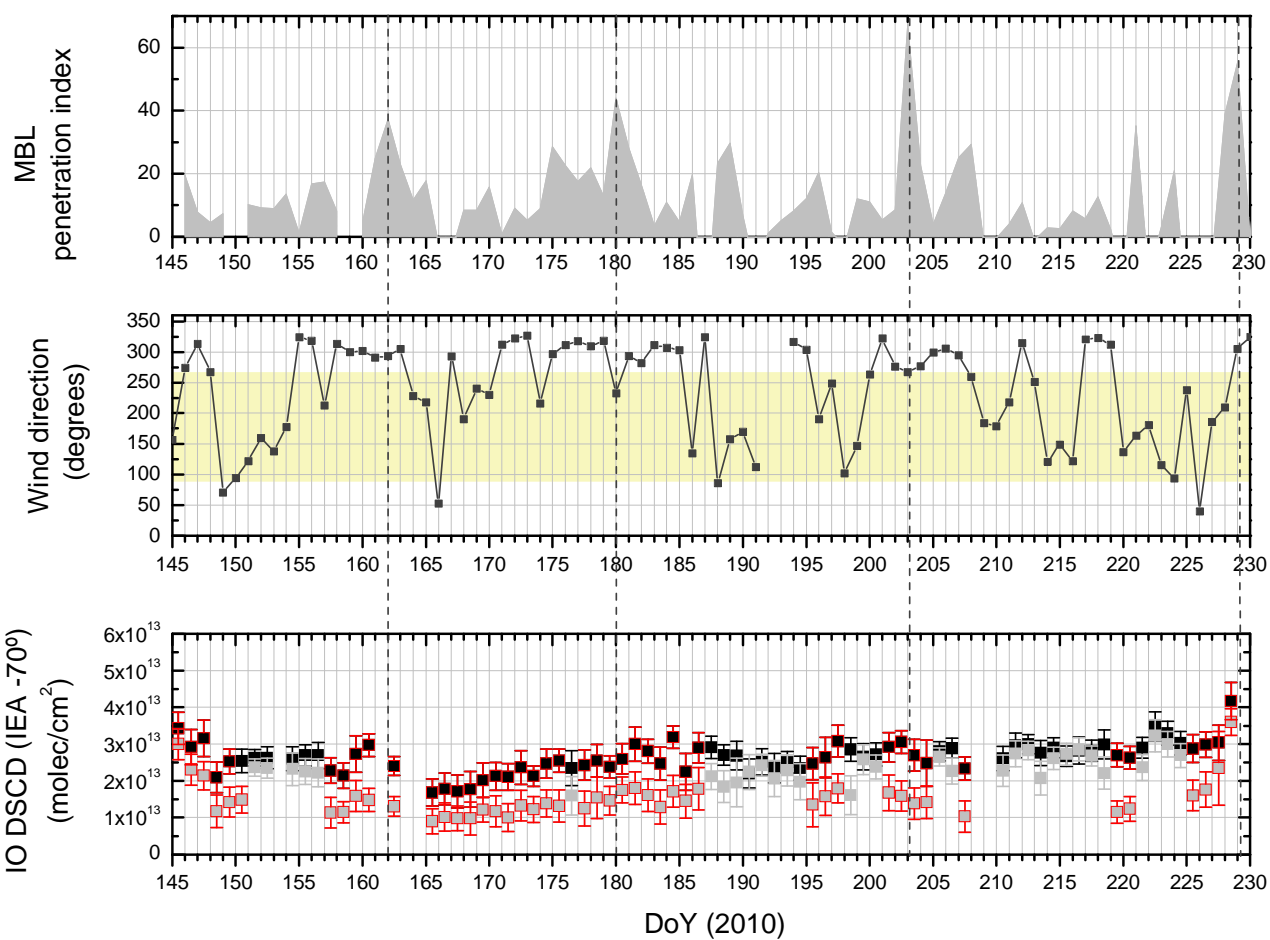

Fig. 7. Upper panel, MBL penetration index for $\mathrm{H}_{2} \mathrm{O}$ (see text). Middle panel, wind direction, shaded area shows South wind. Bottom panel, in dark grey: $\operatorname{IO} \operatorname{DSCDs}\left(0^{\circ}-70^{\circ}\right)$ and in light grey: DSCDs $\left(5^{\circ}-70^{\circ}\right)$ data series. Red encircled points are pristine days. Vertical dashed lines shows maxima of MBL penetration index for $\mathrm{H}_{2} \mathrm{O}$ (see text).

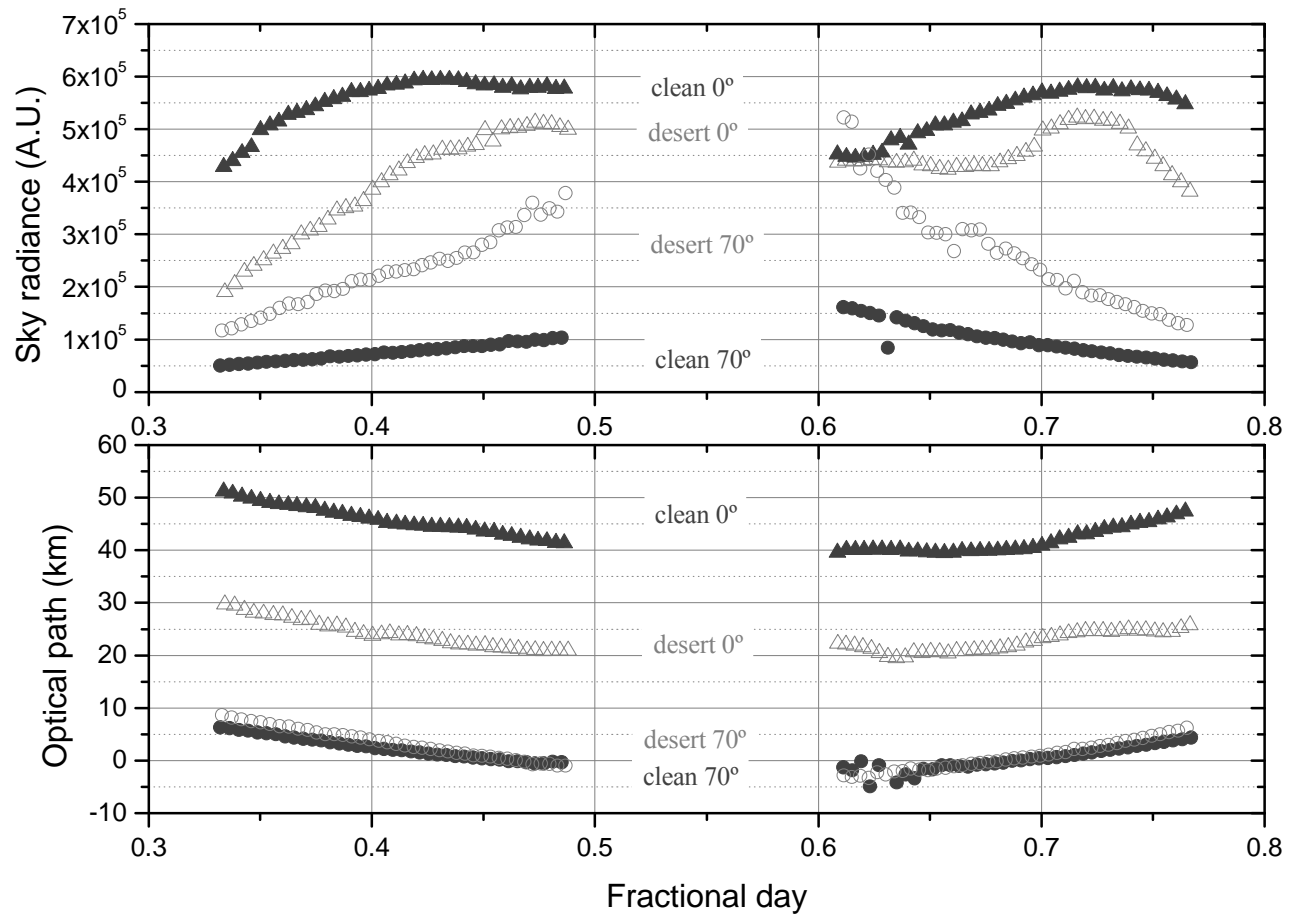

Fig. 8. Upper panel, sky radiance at zenith (circles) and horizon (triangles) for a clean (dark grey) and desert (grey) days. Bottom panel, differential optical path for the same cases as upper panel. Clean is day 181/2010 (30 June). Desert is day 190/2010 (9 July). 
the sky dome with little dependence on elevation angle (also observed by Wagner et al., 2002).

$\mathrm{O}_{4}$ is a good proxy of the length of the mean optical path. Since the vertical oxygen distribution varies only slightly, changes in solar radiation absorption by $\mathrm{O}_{4}$ have to be related to changes in path. Figure 8 (lower panel) shows an estimation of the differential path (in $\mathrm{km}$ ) computed as the $\mathrm{O}_{4}$ measured slant column divided by the concentration at the level of the station. Here the differential path is the difference between any path and the path corresponding to the reference spectrum at zenith. The results shows how a strong reduction in the path takes place in heavy Saharan aerosol conditions at lower elevation angles $\left(0^{\circ}\right)$ whereas at high angles $\left(70^{\circ}\right)$ almost no change is observed. Due to high aerosol loading, solar radiation is scattered closer to the instrument than on clear days. As previously mentioned, under these conditions little difference between IO DSCDs at $0^{\circ}$ and at $70^{\circ}$ IEA is observed. Unidentified structures appear in the residuals of DOAS analysis, resulting in fitting errors larger than $50 \%$ (from $2.5 \times 10^{-4}$ to $4.5 \times 10^{-4} \mathrm{RMS}$ ), thus increasing the uncertainties in the retrieved IO column.

The observed IO increases for the IEA $70^{\circ}$ measurements during the Saharan dust events. As shown in Fig. 8, the $70^{\circ}$ IEA AMF suffers essentially no change. LIBRADTRAN Radiative transfer model exercises in multiple scattering (not shown), assuming an AOD at 500nm equal to one above the station, agree with the observations. Calculations show that very little increase in the $\mathrm{O}_{4}$ zenith AMF occurs when a dense aerosol layer is included. If we assume a background of IO in the FT (see subsection "Radiative transfer calculations"), then the vertical $\mathrm{IO} / \mathrm{O}_{4}$ ratio would remain nearly constant and observed DSCD increases can be explained if larger IO concentrations at the level of the station and above are present. Thus, observed increases in the DSCDs must be due to larger IO concentrations in the FT above the station. An IO enhanced airmass travelling inside the aerosol layer should be viewed in the zenith measurements when evaluated with a clear sky reference. In contrast, at $0^{\circ}$ elevation, the enhancement is compensated for by the strong decrease in the path resulting in a slight reduction of the DSCD.

Saharan dust events are associated with a change in wind direction from NW to S-SE two to three days before the arrival of the dust. The air temperature profile is modulated by the vertical dust distribution and the trade wind inversion is replaced by the inversion at the base of the dust cloud. Under these conditions, the composition of air reaching the station is dependent on the history of the airmass. $\mathrm{O}_{3}$ presents concentrations inside the dust cloud up to $50 \%$ lower than for dust free conditions (Bonasoni et al., 2004).

Several aircraft campaigns have reported observations of sub-pptv levels of $\mathrm{CH}_{3} \mathrm{I}$ in the free troposphere (Bell et al., 2002, and references therein). $\mathrm{CH}_{3} \mathrm{I}$ emitted from the oceans has a local lifetime of $\sim 7$ days and thus can reach the free troposphere where its photolysis can provide a source of reactive iodine in this region of the atmosphere. Furthermore,
Williams et al. (2007) found clear enhancements in $\mathrm{CH}_{3} \mathrm{I}$ concentrations by a factor ranging from 2 to 14 during dust events measurements carried out both at Izaña and at sea level. To explain their observations they considered a mechanism involving the stimulation of $\mathrm{CH}_{3} \mathrm{I}$ production, either due to contact of dust aerosols with surface sea water and later transport to the observatory level or by contact with moist sea salt aerosols following dust coalescence. Similarly to $\mathrm{CH}_{3} \mathrm{I}$, there is no delay between the arrival of the dust and the increase in IO in our observations. Although a connection between the enhancements of both species during severe Saharan outbreaks looks reasonable, the explanation of this possibility is beyond the scope of this work and further investigation is required to determine whether the increase of $\mathrm{CH}_{3} \mathrm{I}$ in the presence of low $\mathrm{O}_{3}$ influences the IO concentration or if there are other mechanisms or IO precursors involved.

\section{Conclusions}

Three months of MAX-DOAS measurements from the subtropical station of Izaña starting in May 2010 show the presence of background levels of IO in the free troposphere.

IO has been observed every day of measurements, indicating that the presence of IO in the FT is not an occasional feature. The mean value of the IO DSCD between IEA $5^{\circ}$ and vertical pointing scattered spectra for clean days during the reported measurement period is $1.52 \times 10^{13}$ molec cm-2 with a day-to-day variation of $33 \%$.

The diurnal variation on clear days shows a minimum at local noon and slightly larger values in the afternoon than in the morning.

Simulated box-AMFs using the NIMO radiative transfer code have shown that the observed IO DSCDs are due to the presence of IO in layers above the station for IEAs greater than $3^{\circ}$.

By using different IO profiles to obtain the corresponding simulated DSCDs with NIMO, it has been demonstrated that the observed IO can only be explained when IO mixing ratios between 0.2 and 0.4 pptv in the FT are considered.

The lack of correlation between IO DSCDs and diurnal variation of the upslope breeze, as well as the shape of IO diurnal variation strongly indicates that these levels of IO are not related to direct ventilation but represent the background for the area, representative of the open ocean FT, at least near the Canary archipelago. This work constitutes, to our knowledge, the first time that column densities of IO are reported in the FT.

Finally, systematic enhancements during Saharan dust events are observed, supporting the explanation proposed by Williams et al. (2007) of the existence of a mechanism that introduces significant amounts of IO precursors at the level of the station during such events. 
Additional measurements are required to determine the sources of IO in the FT, as well to elucidate the mechanisms that lead to the observed enhancements of IO during Saharan dust events.

Acknowledgements. We acknowledge the support of the European Commission through the GEOmon (Global Earth Observation and Monitoring) Integrated Project under the 6th Framework Program (contract number FP6-2005-Global-4-036677) and NORS (Demonstration Network Of ground-based Remote Sensing Observations in support of the GMES Atmospheric Service) Integrated Project under the 7th Framework Program (contract number FP7-SPACE2011-284421). The authors thank Ramón Ramos and the CIAI staff for their support at Izaña Observatory and the Sieltec team for instrument maintenance. We thank Philippe Goloub for his effort in establishing and maintaining AERONET Izaña site.

We thank Alberto Redondas for providing the altitude of the thermal inversion data at Tenerife during the period 2008 to 2011 .

Edited by: R. Volkamer

\section{References}

Alicke, B., Hebestreit, K., Stuzt, J., and Platt, U.: Iodine oxide in the marine boundary layer, Nature, 387, 572-573, 1999.

Allan, B. J., McFiggans, G., and Plane, J.: Observations of iodine monoxide in the remote boundary layer, J. Geophys. Res., 105, 14363-14369, 2000.

Aschmann, J., Sinnhuber, B.-M., Atlas, E. L., and Schauffler, S. M.: Modeling the transport of very short-lived substances into the tropical upper troposphere and lower stratosphere, Atmos. Chem. Phys., 9, 9237-9247, doi:10.5194/acp-9-9237-2009, 2009.

Bell, N., Hsu, L., Jacob, D. J., Schultz, M. G., Blake, D. R., Butler, J. H., King, D. B., Lobert, J. M., and Maier-Reimer, E.: Methyl iodide: Atmospheric budget and use as a tracer of marine convection in global models. J. Geophys. Res., 107, 4340, doi:10.1029/2001JD001151, 2002.

Bloss, W. J., Lee, J. D., Jonson, G. P., Sommariva, R., Heard, D. E., Saiz-Lopez, A., Plane, J. M. C., McFiggans, G., Coe, H., Flynn, M., Williams, P., Richard, A. R., and Flemiing, Z. L.: Impact of Halogen Monoxide Chemistry upon Boundary Layer $\mathrm{OH}$ and $\mathrm{HO}_{2}$ Concentrations at a Coastal Site, J. Res. Lett., 32, L06814, doi:10.1029/2004GL022084, 2005.

Bogumil, K., Orphal, J., Flaud, J.-M., and Burrows, J.-P.: Vibrational progressions in the visible and near ultraviolet absorption spectrum of ozone, Chem. Phys. Lett., 349, 241-248, 2001.

Bogumil, K., Orphal, J., Homann, T., Voigt, S., Spietz, P., Fleischmann, O. C., Vogel, A., Hartmann, M., Bovensmann, H., Frerick, J., and Burrows, J. P.: Measurements of molecular absorption spectra with the SCIAMACHY pre-flight model: Instrument characterization and reference data for atmospheric remote sensing in the 230-2380 nm region, J. Photochem. Photobiol. A, 157, 167-184, 2003

Bonasoni, P., Cristofanelli, P., Calzolari, F., Bonafè, U., Evangelisti, F., Stohl, A., Zauli Sajani, S., van Dingenen, R., Colombo, T., and Balkanski, Y.: Aerosol-ozone correlations during dust transport episodes, Atmos. Chem. Phys., 4, 1201-1215, doi:10.5194/acp4-1201-2004, 2004.
Butz, A., Bösch, H., Camy-Peyret, C., Chipperfield, M. P., Dorf, M., Kreycy, S., Kritten, L., Prados-Román, C., Schwärzle, J., and Pfeilsticker, K.: Constraints on inorganic gaseous iodine in the tropical upper troposphere and stratosphere inferred from balloon-borne solar occultation observations, Atmos. Chem. Phys., 9, 7229-7242, doi:10.5194/acp-9-7229-2009, 2009.

Chameides, W. L. and Davis, D. D.: Iodine: Its possible role in tropospheric photochemistry, J. Geophys. Res., 85, 7383-7393, 1980.

Chance, K. V. and Spurr, R. J. D.: Ring effect studies: Rayleigh scattering, including molecular parameters for rotational Raman scattering, and the Fraunhofer spectrum, Appl. Optics, 36, 5224 5230, 1997.

Davis, D., Crawford, J., Liu, S., McKeen, S., Bandy, A., Thornton, D., Rowland, F., and Blake, D.: Potential impact of iodine on tropospheric levels of ozone and other critical oxidants, J. Geophys. Res., 101, 2135-2147, 1996.

Fayt, C. and Van Roozendael, M.: WinDOAS 2.1. User Manual, IASB-BIRA, 2001.

Font, I.: El Tiempo Atmosférico de las Islas Canarias, Servicio Meteorológico Nacional (INM), Serie A, No. 26, 1956.

Gil, M., Yela, M., Gunn, L. N., Richter, A., Alonso, I., Chipperfield, M. P., Cuevas, E., Iglesias, J., Navarro, M., Puentedura, O., and Rodríguez, $\mathrm{S} .: \mathrm{NO}_{2}$ climatology in the northern subtropical region: diurnal, seasonal and interannual variability, Atmos. Chem. Phys., 8, 1635-1648, doi:10.5194/acp-8-1635-2008, 2008.

Gómez Martín, J. C., Spietz, P., and Burrows, J. P.: Spectroscopic studies of the $\mathrm{I}_{2} / \mathrm{O}_{3}$ photochemistry Part 1: Determination of the absolute absorption cross sections of iodine oxides of atmospheric relevance, J. Photochem. Photobiol. A, 176, 15-38, 2005.

Großmann, K., Tschritter, J., Holla, R, Pöhler, D., Frieß, U., and Platt, U.: MAX-DOAS measurements of $\mathrm{BrO}$ and $\mathrm{IO}$ over the Eastern Tropical North Atlantic. Geophys. Res. Abstr. Vol. 13, EGU2011-8054-1, 2011.

Hay, T. D., Bodeker, G. E., Kreher, K., Schofield, R., Liley, J. B., Scherer, M., McDonald, A. J.: The NIMO Monte Carlo model for box-air-mass factor and radiance calculations, J. Quant. Spectrosc. Radiat. Trans., 113, 721-738, doi:10.1016/j.jqsrt.2012.02.005, 2012.

Huang R.-J., Seitz, K., Buxmann, J., Pöhler, D., Hornsby, K. E., Carpenter, L. J., Platt, U., and Hoffmann, T.: In situ measurements of molecular iodine in the marine boundary layer: the link to macroalgae and the implications for $\mathrm{O}_{3}, \mathrm{IO}, \mathrm{OIO}$ and $\mathrm{NO}_{\mathrm{x}}$, Atmos. Chem. Phys., 10, 4823-4833, doi:10.5194/acp-10-48232010, 2010.

Lamarque, J.-F., Emmons, L. K., Hess, P. G., Kinnison, D. E., Tilmes, S., Vitt, F., Heald, C. L., Holland, E. A., Lauritzen, P. H., Neu, J., Orlando, J. J., Rasch, P. J., and Tyndall, G. K.: CAM-chem: description and evaluation of interactive atmospheric chemistry in the Community Earth System Model, Geosci. Model Dev., 5, 369-411, doi:10.5194/gmd-5-369-2012, 2012.

Mahajan, A. S., Oetjen, H., Saiz-Lopez, A., Lee, J. D., McFiggans, G. B., and Plane, J. M. C.: Reactive iodine species in a semi-polluted environment, Geophys. Res. Lett., 36, L16803, doi:10.1029/2009GL038018, 2009.

Mahajan, A., Plane, J., Oetjen, H., Mendes, L., Saunders, R., Saiz-Lopez, A., Jones, C., Carpenter, L., and McFiggans, G.: Measurement and Modelling of Tropospheric Reactive Halogen 
Species over the Tropical Atlantic Ocean, Atmos. Chem. Phys., 10, 4611-4624, doi:10.5194/acp-10-4611-2010, 2010.

Martinez, M. , Harder, H., Kubistin, D., Rudolf, M., Bozem1, H., Eerdekens, G., Fischer, H., Klupfel, T., Gurk, C., Konigstedt, R., Parchatka, U., Schiller, C. L., Stickler, A., Williams, J., and Lelieveld, J.: Hydroxyl radicals in the tropical troposphere over the Suriname rainforest: airborne measurements, Atmos. Chem. Phys., 10, 3759-3773, doi:10.5194/acp-10-3759-2010, 2010.

McFiggans, G., Plane, M. C., Allan, B. J., Carpenter, L., Coe, H., and O'Dowd, C.: A modelling study of iodine chemistry in the marine boundary layer, J. Geophys. Res., 105, 14371, doi:10.1029/1999JD901187, 2000.

McFiggans, G., Bale, C. S. E., Ball, S. M., Beames, J. M., Bloss, W. J., Carpenter, L. J., Dorsey, J., Dunk, R., Flynn, M. J., Furneaux, K. L., Gallagher, M. W., Heard, D. E., Hollingsworth, A. M., Hornsby, K., Ingham, T., Jones, C. E., Jones, R. L., Kramer, L. J., Langridge, J. M., Leblanc, C., LeCrane, J.-P., Lee, J. D., Leigh, R. J., Longley, I., Mahajan, A. S., Monks, P. S., Oetjen, H., Orr-Ewing, A. J., Plane, J. M. C., Potin, P., Shillings, A. J. L., Thomas, F., von Glasow, R., Wada, R., Whalley, L. K., and Whitehead, J. D.: Iodine-mediated coastal particle formation: an overview of the Reactive Halogens in the Marine Boundary Layer (RHaMBLe) Roscoff coastal study, Atmos. Chem. Phys., 10, 2975-2999, doi:10.5194/acp-10-2975-2010, 2010.

Milford, C., Marrero, C., Martin, C., Bustos, J. J., and Querol, X.: Forecasting the air pollution episode potential in the Canary Islands, Adv. Sci. Res., 2, 21-26, 2008.

O’Dowd, C. D., Hämeri, K., Mäkelä, J. M., Pirjola, L., Kulmala, M., Jennings, S. G., Berresheim, H., Hansonn, H.-C., de Leeuw, G., Kunx, G. J., Allen, A. G., Hewitt, C. N., Jackson, A., Viisanen, Y., and Hoffmann, T.: J. Geophys. Res., 107, 8108, doi:10.1029/2001JD000555, 2002.

Ordóñez, C., Lamarque, J.-F., Tilmes, S., Kinnison, D. E., Atlas, E. L., Blake, D. R., Sousa Santos, G., Brasseur, G., and Saiz-Lopez, A.: Bromine and iodine chemistry in a global chemistry-climate model: description and evaluation of very short-lived oceanic sources, Atmos. Chem. Phys., 12, 1423-1447, doi:10.5194/acp12-1423-2012, 2012.

Peters, C., Pechtl, S., Stutz, J., Hebestreit, K., Hönninger, G., Heumann, K. G., Schwarz, A., Winterlik, J., and Platt, U.: Reactive and organic halogen species in three different European coastal environments, Atmos. Chem. Phys., 5, 3357-3375, doi:10.5194/acp-5-3357-2005, 2005.

Platt, U. and Stutz, J.: Differential Optical Absorption Spectroscopy: Principles and Applications, Springer-Verlag, Berlin, Germany, 2008.

Read, K. A., Mahajan, A. A., Carpenter, L. C., Evans M. J., Faria, B. V., Heard, D. E., Hopkins, J. R., Lee, J. D., Moller, S., Lewis, A. C., Mendes, L., McQuaid, J. B., Oetjen, H., Saiz- Lopez, A., Pilling, M. J., and Plane, J. M. C.: Extensive halogen-mediated ozone destruction over the sub-tropical Atlantic Ocean, Nature, 453, 1232-1235, 2008.

Rodgers, R. C.: Inverse methods for atmospheric soundings: Theory and practise, World Scientific Publishing, 2000.

Roscoe, H. K., Van Roozendael, M., Fayt, C., du Piesanie, A., Abuhassan, N., Adams, C., Akrami, M., Cede, A., Chong, J., Cémer, K., Friess, U., Gil Ojeda, M., Goutail, F., Graves, R., Griesfeller, A., Grossmann, K., Hemerijckx, G., Hendrick, F., Herman, J., Hermans, C., Irie, H., Johnston, P. V., Kanaya, Y.,
Kreher, K., Leigh, R., Merlaud, A., Mount, G. H., Navarro, M., Oetjen, H., Pazmino, A., Perez-Camacho, M., Peters, E., Pinardi, G., Puentedura, O., Richter, A., Schönhardt, A., Shaiganfar, R., Spinei, E., Strong, K., Takashima, H., Vlemmix, T., Vrekoussis, M., Wagner, T., Wittrock, F., Yela, M., Yilmaz, S., Boersma, F., Hains, J., Kroon, M., Piters, A., and Kim, Y. J.: Intercomparison of slant column measurements of $\mathrm{NO}_{2}$ and $\mathrm{O}_{4}$ by MAX-DOAS and zenith-sky UV and visible spectrometers, Atmos. Meas. Tech., 3, 1629-1646, doi:10.5194/amt-3-1629-2010, 2010.

Rothman, L. S., Gordon, I. E., Barbe, A., Benner, D. C , Bernath, P. F., Birk, M., Boudon, V., Brown, R., Campargue, A., Champion, J.-P., Chance, V, Coudert, L. H., Dana, V., Devi, V. M., Sally, S., Flaud, J.-M., Gamache, R. R., Goldman, A., Jacquemart, D., Kleiner, I., Lacome, N., Lafferty, W. J., Mandin, J.-Y., Massie, S. T., Mikhailenko, S. N., Miller, C. E., Moazzen-Ahmadi, N., Naumenko, O. V., Nikitin, A. V., Orphal, J., Perevalov, V. I., Perrin , A., Predoi-Cross, A., Rinsland, C. P., Rotger, M., Simeckova, M., Smith, M. A. H., Sung, K., Tashkun, S. A., Tennyson J., Toth, R. A., Vandaele, A. C., and Vander Auwera, J.: The HITRAN 2008 molecular spectroscopic database, J. Quant. Spectrosc. Radiat. Transf., 110, 533-572, 2009.

Saiz-Lopez, A. and Plane, J. M. C.: Novel iodine chemistry in the marine boundary layer, Geophys. Res. Lett., 31, L04112, doi:10.1029/2003GL019215, 2004.

Saiz-Lopez, A., Mahajan, A. S., Salmon, R. A., Bauguitte, S., Jones, A. E., Roscoe, H. K., and Plane, J. M. C.: Boundary layer halogens in coastal Antarctica, Science, 317, 348-351, 2007a.

Saiz-Lopez, A., Chance, K., Liu, X., Kurosu, T. P., and Sander, S. P.: First Observation of Iodine Oxide from Space, Geophys. Res. Lett., 34, L12812, doi:10.1029/2007GL030111, 2007 b.

Schönhardt A., Richter, A., Wittrock, F., Kirk, H., Oetjen, H., Roscoe, H. K., and Burrows, J. P.: Observations of iodine monoxide columns from satellite, Atmos. Chem. Phys., 8, 637-653, doi:10.5194/acp-8-637-2008, 2008.

Smirnov, A., Villevalde, Y., O’Neill, N., Royer, A., and Tarussov, A.: Aerosol optical depth over the oceans: Analysis in terms of synoptic air mass types, J. Geophys. Res., 100, 16639-16650, doi:10.1029/95JD01265, 1995.

Vandaele, A. C., Hermans, C., Simon, P. C., Carleer, M., Colins, R., Fally, S., Mérienne, M. F., Jenouvrier, A., and Coquart, B.: Measurements of the $\mathrm{NO}_{2}$ Absorption Cross-Sections from $42000 \mathrm{~cm}-1$ to $10000 \mathrm{~cm}^{-1}(238-1000 \mathrm{~nm})$ at $220 \mathrm{~K}$ and 294 K, J. Quant. Spectrosc. Rad. Transfer, 59, 171-184, doi:10.1016/S0022-4073(97)00168-4, 1998.

Vogt, R., Sander, R., Von Glasow, R., and Crutzen, P. J.: Iodine Chemistry and its Role in Halogen Activation and Ozone Loss in the Marine Boundary Layer: A Model Study, J. Atmos. Chem., 32, 375-395, doi:10.1023/A:100617901037, 1999.

Volkamer, R., Spietz, P., Burrows, J., and Platt, U.: Highresolution Absorption Cross-Section of Glyoxal in the UV/Vis and IR Spectral Ranges, J. Photochem. Photobiol., 172, 35-46, doi:10.1016/j.jphotochem.2004.11.011, 2005.

Wada, R., Beames, J. M., and Orr-Ewing, A. J.: Measurement of IO radical concentrations in the marine boundary layer using a cavity ring-down spectrometer, J. Atmos. Chem., 58, 69-87, doi:10.1007/s10874-007-9080-z. 2009.

Wagner, T., Dix, B., Friedeburg, C.v., Friess, U., Sinreich, R., and Platt, U.: MAX-DOAS O4 measurements: A new technique to derive information on atmospheric aerosols - Principles and 
information content, J. Geophys. Res., 109, D22205, doi:101029/2004JD0044904, 2004.

Whalley, L. K., Furneaux, K. L., Gravestock, T., Atkinson, H. M., Bale, C. S. E., Ingham, T., Bloss, W. J., and Heard, D. E.: Detection of Iodine Monoxide Radicals in the Marine Boundary Layer using Laser Induced Fluorescence Spectroscopy, J. Atmos. Chem., 58, 19-39, 2007.

Williams, J., Gros, V., Atlas, E., Maciejczyk, K., Batasaikhan, H., Schöler, H. F., Forster, C., Quack, B., Yassaa, N., and Van Digenen, R.: Possible Evidence for a Connection between Methyl Iodide Emissions and Saharan Dust, J. Geophys. Res., 112, D07303, doi:1029/2005JD006702, 2007.
Wittrock, F., Oetjen, H., Richter, A., Fietkau, S., Medeke, T., Rozanov, A., and Burrows, J. P.: MAX-DOAS measurements of atmospheric trace gases in Ny-Ålesund - Radiative transfer studies and their application, Atmos. Chem. Phys., 4, 955-966, doi:10.5194/acp-4-955-2004, 2004. 